\title{
The Third Intermediate Period Lintel at the Egyptian Museum
}

\section{Cairo (JE.2213)}

\author{
Bassem Ahmed
}

\author{
Faculty of Arts -Ain Shams University-Egypt \\ bassemyossef65@gmail.com
}

\begin{abstract}
This door lintel was found at Sheikh Abd El-Qurna at Thebes and is currently housed at Cairo Museum. It was reused and contained the names of the two scribes, imn $h t p$ and $p 3-s ̌ d-h n s w$ from $22^{\text {th }}$ till $23^{\text {rd }}$ dynasty. There is no tomb that had the names of these two scribes at Sheikh Abd El-Qurna at Thebes, so either it has not been discovered yet or if there were a close relationship between them as two brothers perhaps buried in the tomb of the $w^{c} b$ priest of Khonsu, the scribe of the house of the gold of Amun and the scribe of the treasury of the temple of Amun, $h n s w-m s^{1}$ exist in the same place. This scribe had a son his name and titles were the $w^{c} b$ priest of Khonsu $h r-h b y t^{2}$, so he might had been the grandfather of the tow scribes.
\end{abstract}

Keywords: Door, lintel, third intermediate period, scribe, Sheikh Abd El-Qurna, Thebes, Khonsu, temple of Amun

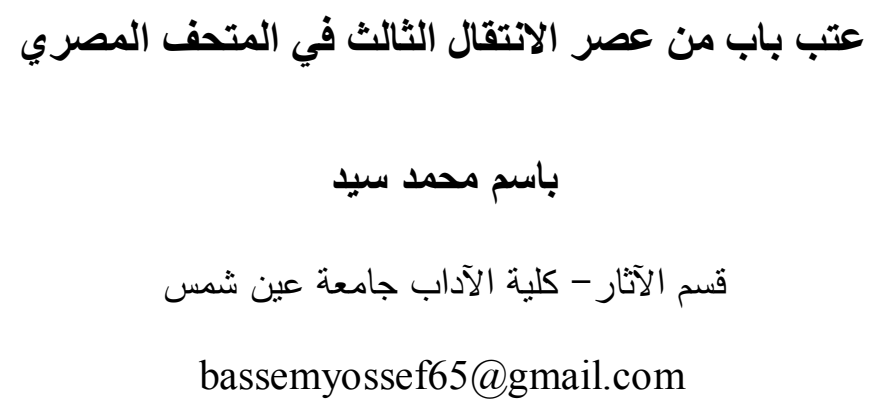

$$
\begin{aligned}
& \text { الملخص: تتعرض هذه المقالة لعتب باب يرجع لعصر الانتقال الثالث نم العثور عليه في منطقة شيخ عبد القرنة } \\
& \text { في طيبة، وهو موجود حاليًا في المتحف المصري بالقاهرة، ومن الواضح أن هذا العتب قد أعيد استخدامه وعليه }
\end{aligned}
$$

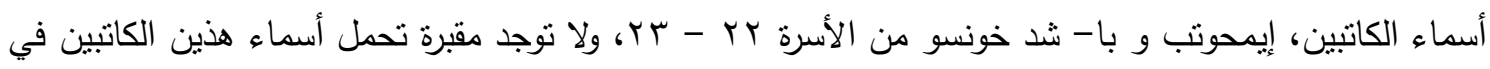

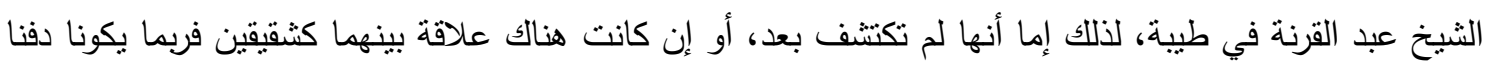

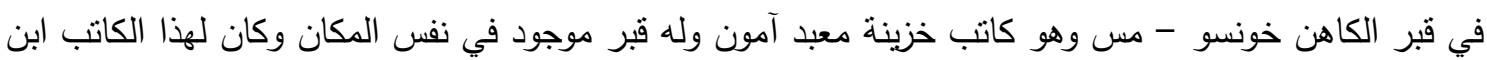

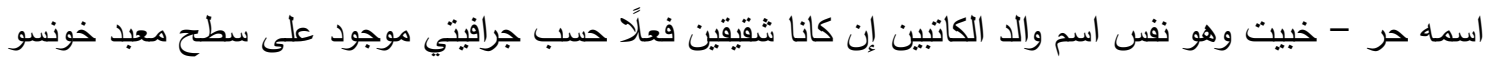

$$
\begin{aligned}
& \text { بالكرنك يعود لنفس الفترة الزمنية الني عاثنا فيها لذلك قد يكون خونسو - مس هو جد لهذين الكاتبين. } \\
& \text { الكلمات الدالة: باب، عنبة، الفترة المتوسطة الثالثة، الكاتب، الثيخ عبد القرنة، طيبة، خونسو، معبد آمون. }
\end{aligned}
$$

\footnotetext{
${ }^{1}$ PM. I², 672; PN I, 271,7

2 Jacquet Gordon, "The Graffiti of Khonso Temple Roof at Karnak", OIP 123 (Chicago: 2003): Graffito no.332-333. 117
} 


\section{Description:}

This rectangular sandstone door lintel measures $102 \mathrm{~cm} \times 49 \mathrm{c} \mathrm{m}$, the text of this lintel is written above another older text which referred that this block was reused from older period, the hieroglyphs and the scenes are in sunken relief. The right part of the text consists of nine columns of hieroglyphs, but the ninth one was destroyed. The left part consists of eight columns of hieroglyphs. The text is on the upper part of the lintel upon the depictions of the two brothers and their wives containing the htp di $n s w$, offering formula, the names and the titles of the deceased and each column of the text is separated from the next by a vertical line. Below the text is a relief divided into two parts, each part represents one of the two scribes with his wife sitting opposite to the other.

The right part of the relief shows the scribe imn htp, wearing a short simple wig that shows his ears, a simple collar with no details and a long skirt, holding in his left hand a lotus flower in front of his nose and grasping a handkerchief in his right hand. His wife 3t. $i$ wears a long wig, showing her ears, a simple collar with no details and a long tight dress; she puts her left arm on her husband's left shoulder and holds his right arm with her right hand. They are sitting on a chair with lion legs and a low back, standing in front of them is an offering table, upon which is a calf head, a wine vase, fruits, a pair of slaughtered birds and a bouquet of roses and under it there is a perfume jar. On the other side of the offerings table stands a woman wearing the same wig, collar and dress as 3t.i, extending her right hand. Both the offering and identification texts that accompany this figure are damaged.

The left part of the relief shows the scribe $p 3-s ̌ d-h n s w t h^{\top} t$ has the same wig, clothes and collar of his brother imn htp and he also holds a lotus flower up to his nose with his right hand and a handkerchief in his left hand. The only difference between them is that $p 3-\check{s} d-h n s w$ has a small beard and his wife $t 3 b 3 k t n(t) M w t$ wears the same wig, collar and dress as 'Imn htp's wife and she adopts a similar pose. Like the first, the second couple sit on a chair with lion legs and a low back, before an offerings table on which two thighs of calf, a wine vase, fruits and a bouquet of roses and under the table there is a perfume jar.

The upper corners of the lintel were broken, and it was cracked in the middle.

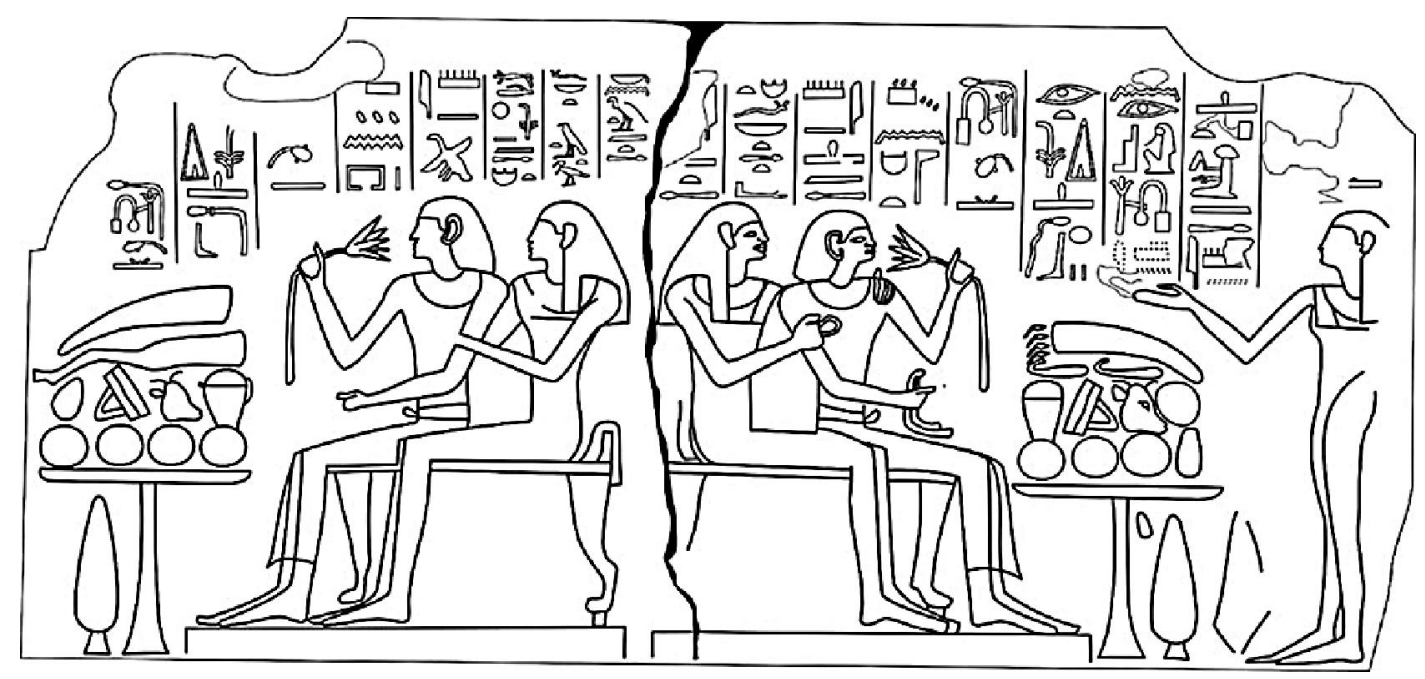

Fig.1 


\section{Text Study:}

\section{A. The Right Part:}

$1-$

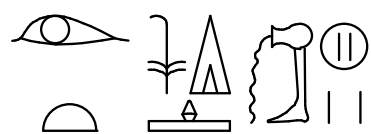

"Irt htp di $n s w$ web sp-snw"

Making the offering which the king gives to be purified twice.

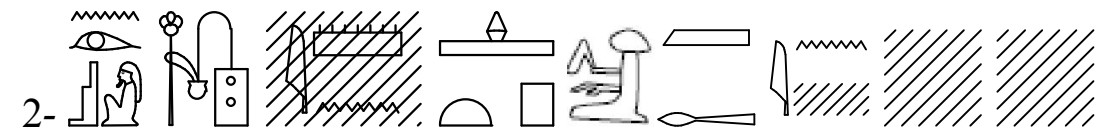

"N Wsir š̌ Imn ḥtp mวّ hrw in // // ///"

To the deceased writer Amun Hotep ${ }^{1}$, true of voice, by ||||$I|I| I|I|$

$3-$

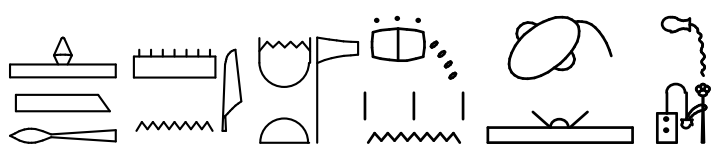

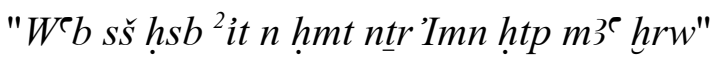

The priest writer counter of barley (taxes) of God's wife, Amun hotep true of voice.

4

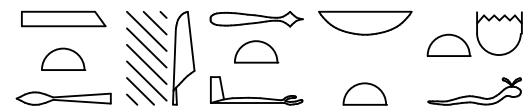

"ḥmt. fnbt ${ }^{\mathrm{C}} 3 t . i^{3} \mathrm{~m}^{\mathrm{C}} \mathrm{t}$ h hrw"

His wife the lady '3t.i, true of voice.

\section{B. The left part:}

$5-$

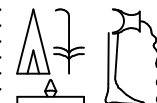

"Irt ḥtp dỉ nsw w`b n Wsir š̌ w`b hasb //I/I/I/I/I//"

Making the offering which the king gives, to the deceased priest writer counters (scribe of taxes) $|I| I|I| I|I|$

"it n pr'Imn P3-šd-hnnsw ${ }^{l} 3^{e}$ hrrw"

\footnotetext{
${ }^{1}$ Gordon J., "The Graffiti of Khonso", 115, Graffito no.278. 96, PN I, 247, 15 Dyn. 22

${ }^{2} \mathrm{~Wb}$ 3, 167. 8-10; L. Lesko, A Dictionary of Late Egyptian, III (USA: B C Scribe Pubns, Providence 1987), 96; W. Ward, Index of Egyptian Administrative and Religious Titles of the Middle Kingdom (Beirut: American University of Beirut: 1982), 162 no. 1405

${ }^{3}$ PN I. 59,8
} 
of barley of the temple of God Amun, Pashed- Khonso, true of voice.

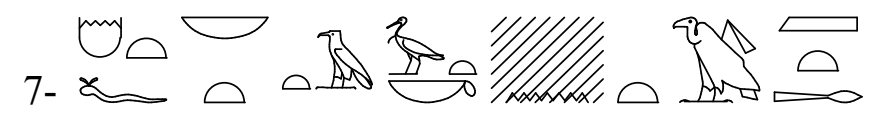

"hmt.f nbt t3 b3kt n(t) Mwt $\mathrm{m}^{3} \mathrm{c} t$ hrw"

His wife lady Ta Baket nt Mut, true of voice.

\section{Comment:}

a) This lintel was reused in the two brothers tomb because the current text was overwriting another older one and the traces of the older text still exist especially at the right part which belongs to 'Imn htp and between the two wives.

b) The column of hieroglyphs that contains the caption for the lady who is making the offerings on the table is damaged and her name is not preserved.

c) In line (2), the name of Amon from the name of the deceased Imn htp is damaged.

d) In line (2), the determinative at the end of imn htp's name ${ }^{3}$ is written In $_{\text {instead of }}$ the usual

e) $s \check{s} h s b$ : This title was known since the Old Kingdom and it appears often during the New Kingdom. The scribes who bear this title worked in the fields to collect information about the crops for calculating the state taxes. ${ }^{4}$

f) $W^{c} b s \check{s} h s b$ : These two titles are uncommon and they appeared during the Late Period. They are perhaps related to the priest scribe who counted grain for the fields of the temples or who calculated taxes.

g) At line no.(5), the left part of the lintel has lost part of its corner, which contains parts of the htp di nsw formula (irt and $\mathrm{n} w \operatorname{sir} w^{\complement} b$ sš are lost).

h) imn htp, father of priest of Amon $P 3$ di $m n w$ and son of the $w^{c} b$ priest of Khonsu $h r-$

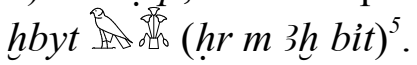

i) $p 3-\check{s} d-h n n s w$ : The $w^{\ulcorner} b$ priest of Khonsu son of $h r-h b y t, 22^{\text {nd }}$ till $23^{\text {rd }}$ Dynasty ${ }^{6}$.

j) hnsw ms: His tomb was dicovered at the Early of the $19^{\text {th }}$ century, its contents were dispersed, in Porter and Moss ${ }^{7}$. It was mentioned that this tomb belongs to hnsw ms and his family, so if there is a family connection with our two scribes they may have been buried in the same tomb.

\footnotetext{
${ }^{1}$ PN I. 119, 18; Gordon J., "The Graffiti of Khonso", 115, Graffito no. 251, 87

${ }^{2}$ PN I. 356.6

3 F. Daumas.Valeurs phonétiques des signes hiéroglyphiques d'époque gréco-romaine (Montpellier: Université de Montpellier, 1988), 63.1089

${ }^{4}$ Ward, W., Index of Egyptian Administrative, 162.1405; D. B. Redford, The Oxford Encyclopedia of Ancient Egypt, III (Oxford: Oxford University Press, 2003), 191.

${ }^{5}$ Gordon J., "The Graffiti of Khonso", Graffito no. 278. 96; PN I, 247, 15 Dyn. 22

${ }^{6}$ Gordon J., "The Graffiti of Khonso", 115, Graffito no. 251, 87

${ }^{7}$ PM. I' ${ }^{2}, 672$; PN I, 271, 7
} 
k) hmt $n t r^{l}$ : This priestly title was first appeared at the beginning of the New Kingdom and from Dynasty XXI onwards it was always the king's unmarried daughter or sister who was given the title of 'God's Wife' which her role becomes increasingly important.

\section{Conclusion:}

This reused door lintel belonged to two scribes; the $w^{c} b$ priest of Khonsu and the scribe counter of the God's wife, imn htp and the $w^{c} b$ priest of Khonsu and the scribe counter of the temple of the God Amun, $P 3-\breve{s} d-h n n s w$ and their wives. These two scribes were probably sons of the $w^{c} b$ priest of Khonsu $h r-h b y t^{2}$. As shown in the graffiti of the foot at the roof of the temple of Khonsu at Karnak ${ }^{3}$, this lintel dates back to $22^{\text {nd }}$ till the $23^{\text {th }}$ dynasties and comes from their tomb which its position is unknown at Sheikh Abd El-Qurna. There is a tomb from the $21^{\text {th }}$ dynasty that was found at the early of the $19^{\text {th }}$ century and its contents has been dispersed; this tomb belongs to the $w^{c} b$ priest of Khonsu, the scribe of the house of gold of Amun and the scribe of the treasury of the temple of Amun, $h n s w-m s^{4}$ which exist in the same place. This scribe had a son whose name and title was the $w^{c} b$ priest of Khonsu $h r-h b y t^{5}$. He may have been the grandfather grandfather of the two scribes who own this door lentil.

\footnotetext{
${ }^{1}$ Graefe, Erhard, Untersuchungen zur Verwaltung und Geschichte der Institution der Gottesgemahlin des Amun vom Beginn des Neuen Reiches bis zur Spätzeit (Wiesbaden: Otto Harrassowitz, 1981), 101- 4.

2 Hr-xbyt (Hr m Ax bit): PN I. 247, 15 Dyn. 22

${ }^{3}$ Gordon J., "The Graffiti of Khonso", 111, Graffito no. 278 (graffiti of pA-di-mnw son of imn Htp) \& 251(graffiti of pA-Sd-xnsw brother of imn Htp)

${ }^{4}$ PM. I' ${ }^{2}, 672 ;$ PN I, 271, 7

${ }^{5}$ Gordon J., "The Graffiti of Khonso", Graffito no. 332-333. 117
} 


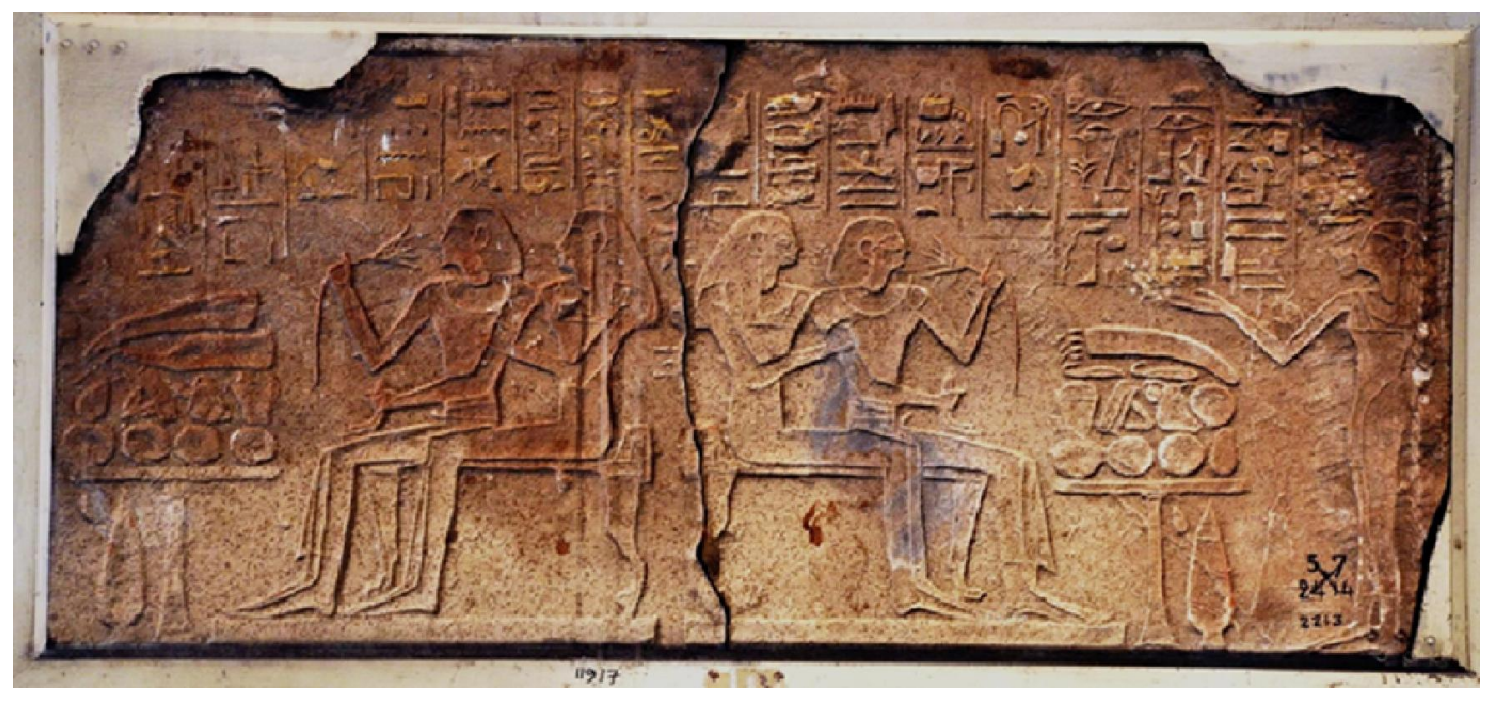

A Late Period Lintel at the Egyptian Museum

(Cairo JE.2213

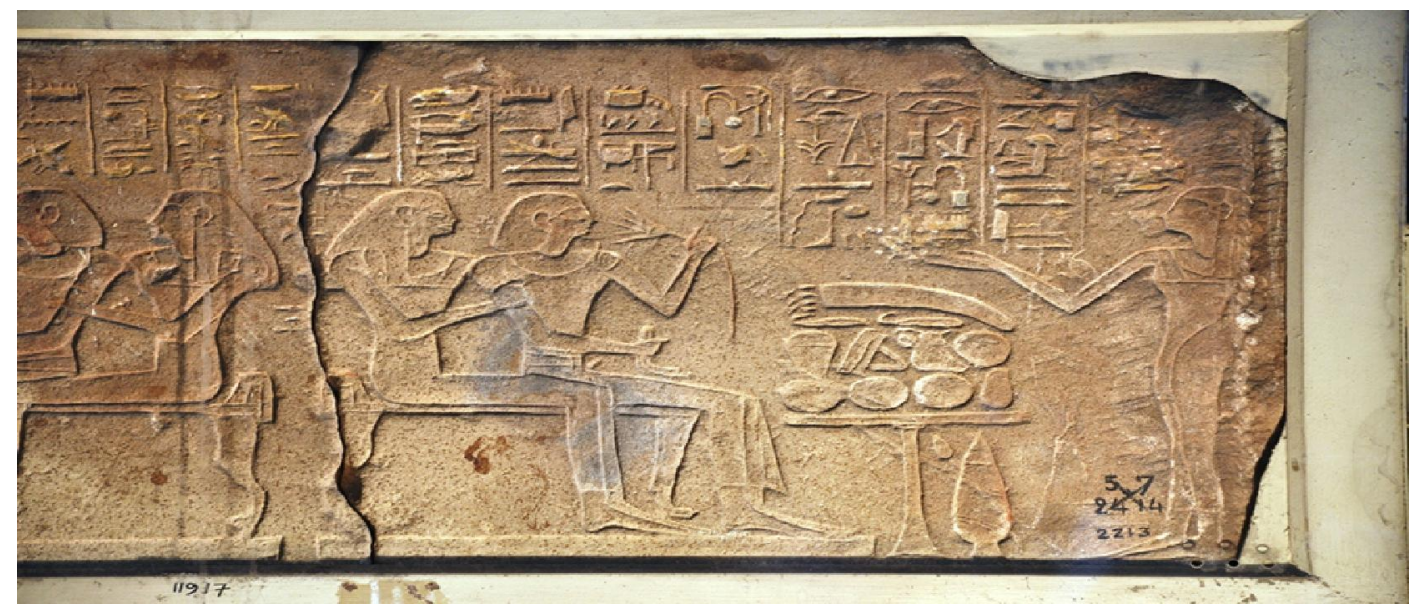

A Late Period Lintel at the Egyptian Museum

(Cairo JE.2213) 


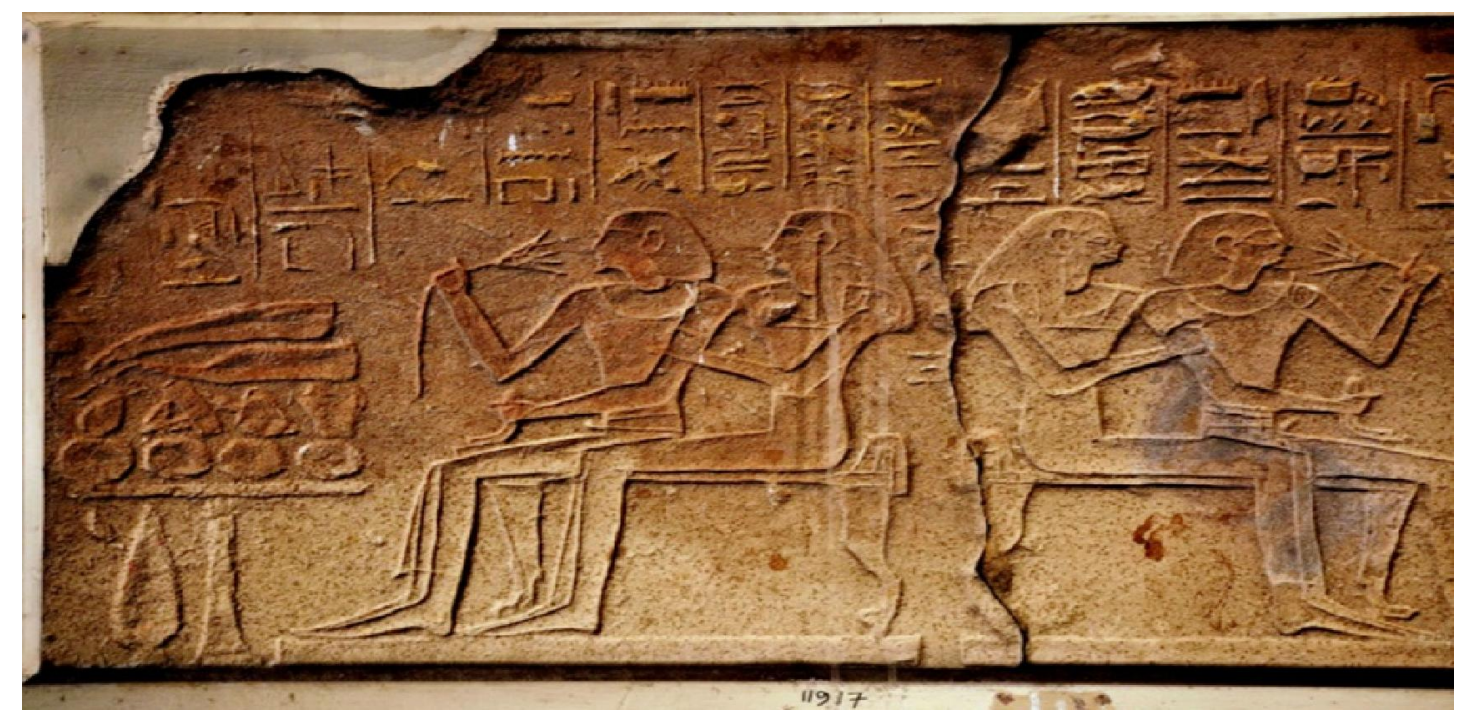

A Late Period Lintel at the Egyptian Museum

(Cairo JE.2213) Left part (detail) 


\section{Bibliography}

- Daumas, F. Valeurs phonétiques des signes hiéroglyphiques d'époque gréco-romaine, Montpellier: Université de Montpellier, 1988

- Erhard, Graefe. Untersuchungen zur Verwaltung und Geschichte der Institution der Gottesgemahlin des Amun vom Beginn des Neuen Reiches bis zur Spätzeit. Wiesbaden: Otto Harrassowitz, 1981.

- Erman A., Grapow H., Wörterbuch der Aegyptischen Sprache,Vols.I-VI, Berlin: Akadmie - Verlag, 1971.

- Gordon, Jacquet. "The Graffiti of Khonso Temple Roof at Karnak", OIP 123, Chicago: 2003.

- Ranke, Hermann. Die Ägyptischen Personennamen, Bd. 1: Verzeichnis der Namen. Glückstadt: J.J. Augustin, 1935.

- Redford, D.B. The Oxford Encyclopedia of Ancient Egypt, III, Oxford: Oxford University Press, 2003.

- L. Lesko, A Dictionary of Late Egyptian, III, USA: B C Scribe Pubns, Providence, 1987.

- Porter B., Moss R.L.B., Burney E.W. Topographical Bibliography of Ancient Egyptian Hieroglyphic Texts, Reliefs and Paintings. Volume I-VII, Oxford: 1960-1995.

- Ward, W. Index of Egyptian Administrative and Religious Titles of the Middle Kingdom, Beirut: American University of Beirut, 1982. 